\title{
ERISA Preemption and the Case for a Federal Common Law of Agency Governing Employer-Administrators
}

\author{
Joshua A.T. Fairfield $\dagger$
}

Imagine that one day you become very sick. You are ill enough that you end up in the hospital, running up a heavy bill. You recover over the next several weeks, and, since your health insurance is completely covered by your job, you feel that you have come out of a bad situation fairly well. Then you get the bad news: your employer has been quietly pocketing your premiums for some time, and the insurer has informed your employer that your insurance has been terminated. You have never dealt directly with the insurer before in your life: premiums, information about policy changes, and even the summaries discussing what coverage the policy actually contains have all been managed by your employer acting on the insurer's behalf.

Now, imagine your confusion when you are informed that you cannot get your health benefits from the insurer. Despite crossing every " $t$ " and dotting every "i," you are cut off. You will be upset to learn that just one year ago, you would have been able to collect full benefits under a state law declaring that when employers perform all of the functions of a plan administrator and take the place of the insurer or the insurer's agent, they are considered to be agents of the insurer. This would have allowed you to collect, since your premium payments delivered to your employer would be deemed to have been delivered directly to the insurer. However, the Supreme Court determined in May 1999 that the Employee Retirement Income Security Act of 1974 ("ERISA")' preempted your state's agency law.' Although federal courts could replace the preempted state agency law with a federal common law rule of agency pursuant to ERISA, they have remained hesitant to do so. ${ }^{3}$

ERISA preemption of state law has created scores of commonly recognized problems. The foremost of these is that ERISA preemp-

$\dagger$ B.A. 1996, Swarthmore College; J.D. Candidate 2001, The University of Chicago.

Pub L No 93-406, 88 Stat 829, codified in various sections of titles 26 and 29 (1994).

2 This hypothetical is based on ERISA's preemption of state agency rules as set forth in UNUM Life Insurance Co of America v Ward, 526 US 358, 378-79 (1999) (reversing in part and affirming in part a Ninth Circuit decision allowing the employee's suit to proceed).

3 See notes 7-9 and accompanying text.

4 See, for example, Jayne Elizabeth Zanglein, Closing the Gap: Safeguarding Participants' 
tion of state law creates a "regulatory vacuum," wherein remedies and causes of action previously available under state law are cut short." Such a vacuum creates a situation of "almost palpable unfairness." The Supreme Court, therefore, held that Congress intended federal courts to develop federal common law remedies pursuant to ERISA in order to fill the vacuum.' Courts have tended to use this power with caution. ${ }^{8}$ In light of this reluctance, Congress has reaffirmed the power and the obligation of the federal judiciary to develop common law rules governing ERISA plans.' An increasing number of decisions have therefore recognized both the necessity of developing federal common law rules ${ }^{10}$ and the strength of Congress's intent that courts do so.

In a recent decision, UNUM Life Insurance Co of America $v$ Ward, ${ }^{11}$ the Supreme Court held that state law (in this case, California law) governing the agency of an employer acting as a plan administrator was preempted by ERISA. ${ }^{12}$ The selection of agency rules for employers who are also plan administrators is important because if the employer is the employee's agent, the employer or the insurance company (or both) can take advantage of the uninformed employee. Ward has created this exact situation by holding that laws determining the employer the insurer's agent have been preempted. This Comment

Rights by Expanding the Federal Common Law of ERISA, 72 Wash U L Q 671, 671-72 (1994) (arguing that ERISA preemption of state rules creates a system of "betrayal without remedy"); William K. Carr and Robert L. Liebross, Wrongs Without Rights: The Need for a Strong Federal Common Law of ERISA, 4 Stan L \& Pol Rev 221, 223-24 (1992-93) (arguing that federal preemption denies remedies, creating serious equity problems).

5 Zanglein, 72 Wash U L Q at 676 (cited in note 4), citing Daniel Fox and Daniel Schaffer, Semi-Preemption in ERISA: Legislative Process and Health Policy, 7 Am J Tax Pol 47, 48 (1988).

6 Zanglein, 72 Wash U L Q at 676 ("The feeling of unfairness is palpable."), citing Smith v Hartford Insurance Group, 6 F3d 131, 146 (3d Cir 1993) (Hutchinson dissenting).

7 See Pilot Life Insurance Co v Dedeaux, 481 US 41, 56 (1987) (stating that Congress intended federal courts to develop a "federal common law of rights and obligations under ERISAregulated plans"). See also Statement of Senator Javits, Employee Retirement Income Security Act of 1974-Conference Report, 93d Cong, 2d Sess, in 120 Cong Rec S 29928, 29942 (Aug 22, 1974) ("It is [ ] intended that a body of Federal substantive law will be developed by the courts to deal with issues involving rights and obligations under private welfare and pension plans.").

8 See note 29.

9 Report to Accompany Recommendations from the Committee on Labor and Education (“Recommendation Report"), HR Rep No 101-247, 101st Cong, 1st Sess 56 (1989).

10 See, for example, Varity Corp v Howe, 516 US 489, 497, 515 (1996) (holding as a matter of federal common law that ERISA $\$ 502$ (a)(3), 29 USC $\$ 1132$ (a)(3) (1994), authorizes lawsuits for individualized equitable relief for breach of fiduciary obligations). See also Firestone Tire \& Rubber Co v Bruch, 489 US 101, 110 (1989) (holding that courts are to develop a "federal common law of rights and obligations under ERISA-regulated plans"); Provident Life \& Accident Insurance Co $v$ Waller, 906 F2d 985, 990 (4th Cir 1990) ("[W]e must ... develop and add to the growing federal common law of ERISA rights and obligations.").

11526 US 358 (1999).

12 Id at 364 ("California's agency law ... does 'relate to' employee benefit plans, and therefore does not occupy ground outside ERISA's preemption clause."). 
will address how courts should fill this vacuum by adopting a federal common law rule, pursuant to ERISA, determining when an employer-administrator is an agent of the employee and when an employer-administrator is an agent of the insurer. This Comment further suggests that such a rule should consist of a fact-sensitive determination of agency, tailored to protect ERISA beneficiaries.

Part I of this Comment discusses the mechanics of ERISA preemption and courts' authority to adopt federal common law pursuant to ERISA. Part II discusses the Ward decision, the California agency law that it supplanted, and agency law more generally. Part III analyzes the options from which courts may select a rule and presents the specific federal common law solution that courts should choose. The selected rule must fulfill the statutory purposes of ERISA (to protect plan beneficiaries), and only a rule that conducts a fact-sensitive analysis of the relationship between the employee, the employer, and the insurer will adequately protect the interests of plan beneficiaries.

\section{ERISA PREEMPTION AND ADOPTION OF FEDERAL COMMON LAW PURSUANT TO ERISA}

\section{A. The ERISA Statute and ERISA Preemption of State Law}

ERISA was enacted in order to address congressional concerns regarding the impact that "the growth in size, scope, and numbers of employee benefit plans" was having on the "continued well-being and security of millions of employees and their dependents."13 Congress sought a unified system of federal rules to govern the administration of employee benefit plans, and therefore drafted ERISA Section 514(a), which preempts state laws "insofar as they ... relate to any [ERISA-covered] employee benefit plan." "14

In New York State Conference of Blue Cross \& Blue Shield Plans $v$ Travelers Insurance $\mathrm{Co}^{15}$ the Supreme Court held that two types of state laws "relate to" employee benefit plans within the meaning of Section 514(a): laws that "mandate employee benefit structures or their administration," and laws "providing alternative enforcement mechanisms." In Ward, the California employer-agency rule was held to "relate to" the ERISA plan because it created a "mandatory con-

16 Id at 658. See also Ward v Management Analysis Company Employee Disability Benefit Plan, 135 F3d 1276, 1287 (9th Cir 1998) (citing Travelers, 514 US at 657-58), affd in part, revd in part as UNUM Life Insurance Co of America $v$ Ward, 526 US 358 (1999). 
tract term" and controlled portions of the relationship between the employer and the insured. ${ }^{17}$

\section{B. State Laws That "Regulate Insurance" Are Saved from ERISA Preemption}

In conjunction with Section 514(a), ERISA also contains a "savings clause," which saves from preemption state laws relating to employee benefit plans that also "[regulate] insurance." The Ward court reiterated the standard for determining whether a state law is considered saved: the court first determines whether, on a "common-sense view of the matter," the state law regulates insurance. ${ }^{19}$ The court also applies a three-prong test to determine whether the state law regulates the "business of insurance" as set forth in the McCarranFerguson Act: ${ }^{20}(1)$ whether the regulation has the "effect of transferring or spreading a policyholder's risk," (2) whether the regulation "is an integral part of the policy relationship between the insurer and insured," and (3) whether the regulation "is limited to entities within the insurance industry." ${ }^{21}$ The law evolved further in Ward itself, where the Court held that a state law satisfying some but not all of the McCarran-Ferguson factors was nevertheless saved from preemption. ${ }^{22}$ If the state law is found, as a matter of "common sense," to regulate insurance or if it meets, on balance, the McCarran-Ferguson factors, then courts will typically find that the state law is saved.

Space for the adoption of federal common law pursuant to ERISA is created by those laws preempted but not saved. Many state rules fall into this gap. ${ }^{24}$ For example, the Supreme Court has held that

17 Ward, 526 US at 374-75, quoting Cisneros v UNUM Life Insurance Co of America, 134 F3d 939, 946 (9th Cir 1998), cert denied, 526 US 1086 (1999).

18 ERISA $\S 514(\mathrm{~b})(2)(\mathrm{A}), 29$ USC $\S 1144(\mathrm{~b})(2)(\mathrm{A})$ (1994). See Ward, 526 US at 373 (holding that California's notice-prejudice rule was a state law regulating insurance and saved from preemption); Hood v Prudential Insurance Co of America, 460 S2d 1227, 1230 (Ala 1984) (holding that Alabama law governs insurance companies and is not preempted by ERISA).

19 Ward, 526 US at 367, citing Metropolitan Life Insurance Co v Massachusetts, 471 US 724, 740 (1985).

20 Pub L No 79-15, 59 Stat 33 (1945), codified as amended at 15 USC $\S 1011$ et seq (1994).

21 Ward, 526 US at 358, citing Metropolitan Life, 471 US at 743.

22 See Ward, 526 US at 373-75.

23 Pilot Life Insurance Co v Dedeaux, 481 US 41, 50 (1987) ("A common-sense view of the word 'regulates' would lead to the conclusion that in order to regulate insurance, a law must not just have an impact on the insurance industry, but must be specifically directed toward that industry.").

24 See, for example, District of Columbia v Greater Washington Board of Trade, 506 US 125, 130-32 (1992) (finding preempted but not saved a District of Columbia statute requiring employers to provide coverage equivalent to the existing health insurance coverage of an employee while the employee received workers' compensation benefits); FMC Corp v Holliday, 498 US 52, 65 (1990) (finding preempted but not saved a section of Pennsylvania's Motor Vehicle Financial Responsibility Law as applied to ERISA plans). See also Zanglein, 72 Wash U L Q at 671-74 
state laws drawn from general common law principles are not limited to entities in the insurance industry, and therefore fail the third McCarran-Ferguson factor. ${ }^{2 s}$

\section{Courts Have the Authority to Adopt Federal Common Law Pursuant to ERISA}

There is no question that courts have the authority to develop a federal common law specifically adapted to ERISA plans. ${ }^{26}$ The Supreme Court has repeatedly recognized this authority. ${ }^{27}$ Legislative history shows that, at the time of the adoption of ERISA, Congress intended federal courts to fill gaps created by ERISA preemption with a federal common law specifically adapted to ERISA plans. ${ }^{28}$ Nevertheless, courts expressed hesitation in exercising this power. ${ }^{29}$ A congressional committee has reaffirmed that, as part of the carefully considered design of ERISA, the federal courts are to "shape legal and equi-

(cited in note 4) (providing examples of preemption without saving of state law remedies for fraudulent denial of benefits and punitive damages).

25 Pilot Life Insurance, 481 US at 51 . Since the Ward court has determined that state employer agency rules fall squarely into the preemption gap, the precise contours of the ERISA preemption gap are beyond the scope of this Comment. For further discussion of the contours of ERISA preemption, see Howard Shapiro, René E. Thorne, and Edward F. Harold, ERISA Preemption: To Infinity and Beyond and Back Again? (A Historical Review of Supreme Court Jurisprudence), $58 \mathrm{La} \mathrm{L} \mathrm{Rev} \mathrm{997,} 1001$ (1998) (analyzing trends in sixteen Supreme Court cases on ERISA preemption).

26 See notes 7-9 and accompanying text. The Supreme Court first addressed the issue of employer agency as a matter of general federal common law (that is, federal common law not pursuant to any statute) in Boseman v Connecticut General Life Insurance Co, 301 US 196, 20405 (1937). Courts had derived authority to develop nonstatutory general federal common law from the Supreme Court's decision in Swift v Tyson, 41 US 1, 18 (1842). Soon after the Boseman decision, however, the Court determined in Erie Railroad Co v Tompkins, 304 US 64, 78-80 (1938), that federal courts could not create or declare general federal common law, but must defer to state law in the absence of a controlling federal statute. As a result, the development of employer agency rules passed into state hands. However, both the Supreme Court and Congress have recognized that courts may develop a federal common law interpreting and filling out the ERISA statute. See note 29 . The ability to adopt federal common law rules pursuant to a statute is different from the unfettered discretion of Swift that the Court rejected in Erie; federal common law rules adopted under ERISA are limited by, and must conform to, the purpose of the statute, which is to protect plan beneficiaries. See Part III.E.1. For a discussion of when courts should exercise this authority (as opposed to whether they have it), see Part II.D.

27 See notes 7-10.

28 See note 7.

29 "[W] must undertake ... [to] develop and add to the growing federal common law of ERISA rights and obligations." Provident Life \& Accident Insurance Co v Waller, 906 F2d 985, 990 (4th Cir 1990). However, the court also remarked: "Despite the power of the federal courts to fill in the interstices of ERISA, we must respect the fact that Congress in creating ERISA has ... 'expressly announced its intention to occupy the field.' Accordingly, we must proceed cautiously ...." Id at 992. Because congressional authorization is a foundation of the courts' authority to develop ERISA common law, congressional intent is clearly relevant to the appropriate scope of these common law remedies. See Parts III.E.1-2 for a more complete discussion of congressional intent regarding ERISA. 
table remedies to fit the facts and circumstances of the cases before them, even though those remedies may not be specifically mentioned in ERISA itself.," ${ }^{30}$ Courts have therefore begun to recognize the need for a federal common law to fill the gaps where ERISA is silent. ${ }^{31}$ As discussed in Part II, the recent preemption of state agency rules determining when an employer administering an insurance plan is deemed the agent of the insurer has created a gap in the law which courts should fill using their power to develop federal common law.

\section{Preemption of State Employer Agency LaW: CAlifornia LAW AND THE WARD DECISION}

\section{A. Agency Law and California's Employer Agency Rule}

1. The law of agency and its impact on the job insurance context.

An agent is a person who, pursuant to authority delegated by a principal, has the power to alter the legal relations of the principal by acting on behalf of or in the place of the principal. ${ }^{32}$ Since the agent acts on behalf of the principal, dealings with an agent acting within the scope of his delegated authority are treated as dealings directly with the principal. ${ }^{33}$ For example, information (such as notice) provided to the agent is imputed to the principal, and contracts entered into by the agent on behalf of the principal are binding on the principal. ${ }^{34}$ Finally, the same entity or person may act as an agent for different parties in succession. $^{35}$ Therefore, an employer who acts as an agent for an employee for one purpose may later act as an agent for an insurer for another purpose.

30 See Recommendation Report, HR Rep No 101-247 at 56 (cited in note 9).

31 See notes 7-10.

32 See Restatement (Second) of Agency § 1 (1958) ("Agency is the fiduciary relation which results from the manifestation of consent by one person to another that the other shall act on his behalf and subject to his control, and consent by the other so to act. The one for whom action is to be taken is the principal. The one who is to act is the agent.").

33 See 3 Am Jur 2d Agency $\$ 2$ at 510 (1986) ("It is ... a consequence of the relationship that whatever an agent does in the lawful prosecution of the transaction entrusted to him is the act of the principal.").

34 See id $\S 281$ at 784 (stating that " [t]he general rule ... is that the principal is chargeable with, and bound by, the knowledge of or notice to his agent received while the agent is acting as such within the scope of his authority"). See also id $\S 89$ at 600 (stating that "[a]n agent may ... be given the express authority to contract on behalf of the principal, or he may have the implied or apparent power to enter into such a contract").

35 See, for example, Paulson v Western Life Insurance Co, 292 Or 38, 636 P2d 935, 942-43, 949 (1981) (holding that an employer may act as an agent for employees or for an insurer at different times, depending on the purpose of the agency and the facts of the matter).

36 Id. 
Whether employers who administer everyday details of group health insurance plans are deemed to be the agents of the plan beneficiaries (that is, employees) or of the insurer is relevant to a number of situations, such as when the master policyholder (the employer): (1) determines an employee's eligibility for insurance in error; (2) fails to remit premiums deducted from the employee's wages to the insurer; (3) wrongfully refuses to accept an employee's premium payments; (4) fails to list the insured employee on the insurance roll; or (5) fails to notify the insurer of an insured's disability. ${ }^{37}$

If the employer who makes the misrepresentation or mistake is acting as the insurer's agent when administering the plan, his or her acts and non-fraudulent mistakes may be imputed to the insurer; if not, the employee is usually denied coverage. ${ }^{38}$ The choice of the rule characterizing employer agency is important, since it directly determines whether the plan beneficiary will be covered in situations where the beneficiary is not at fault.

\section{The California rule of employer agency.}

Where an employer also acts as a plan administrator, California case law, as expressed in Elfstrom v New York Life Insurance Co," holds that "the employer is the agent of the insurer in performing the duties of administering group insurance policies." ${ }^{, 40}$ The Elfstrom court based its agency determination on the fact that the employer was administering the plan in the place of the insurer, that the interests of the insurer and the employer were aligned in the context of plan administration, and that the employee had no control over the administration process. $^{41}$

The Ninth Circuit, in Ward v Management Analysis Co Employee Disability Benefit Plan, ${ }^{42}$ considered whether California's employer

37 See Stephen K. Eugster, Comment, Group Insurance: Agency Characterization of the Master Policy-Holder, 46 Wash L Rev 377,383-88 (1971), for a more thorough discussion of the importance of the agency determination in each of these situations.

38 Id. For a general discussion of the distinct issue of employer liability, see Tina Knight Kukanza, Casenote, Varity Corp. v. Howe: Will it Cause an Increase in Litigation Against Employers Who Administer ERISA Plans?, 48 Mercer L Rev 965, 976 (1997) (discussing the Varity case and its possible implications and suggesting that "Varity opens the door to individual lawsuits against employers who are also plan administrators"). Even if the employer is liable as an ERISA fiduciary (which is in doubt), it may be judgment proof, necessitating an agency rule allowing suit against the insurer.

3967 Cal 2d 503, 432 P2d 731 (1967).

40 Id at 737. See also Sandoval v Raymond James Financial, Inc, 1999 US App LEXIS 20998, *6 (9th Cir) ("California law considers employers to be agents of the insurer, rather than agents of the employee-insureds.").

$41432 \mathrm{P} 2 \mathrm{~d}$ at $737-38$. For a more extensive discussion of the Elfstrom holding, see Parts III.B.1-2.

$42 \quad 135$ F3d 1276 (9th Cir 1998). 
agency rule was preempted by ERISA. The plaintiff, Ward, claimed to have provided timely notice of his disease to his employer, who notified the insurer, UNUM, after the policy's notification time period had expired. ${ }^{43}$ The Ninth Circuit found two grounds on which to reverse the trial court. ${ }^{44}$ The first relied on California's notice-prejudice rule, under which an insurer may not avoid liability for a delay in notification of a claim unless it is established that the insurer suffered actual prejudice as a result thereof. ${ }^{45}$ The Ninth Circuit ruled that the noticeprejudice rule was saved by ERISA's savings clause as a state law regulating insurance. ${ }^{46}$ Second, the Ninth Circuit found that the Elfstrom rule was drawn from general principles of law as applied to the specific insurance situation, and was therefore not a state law "relating to" ERISA plans. ${ }^{47}$ Accordingly, the Ninth Circuit reversed and remanded the case to the district court to determine whether, under Elfstrom, the employer was UNUM's agent, and therefore whether the receipt of notice by the employer was attributed to the insurerprincipal. ${ }^{48}$ The Ninth Circuit's decision in Ward followed the trend of modern state decisions, which tend toward deeming employers the agents of insurers when they administer health plans. This area of evolving law, however, was cut off by ERISA preemption, and has not yet been replaced.

\section{B. The Supreme Court's Decision in Ward}

The Supreme Court granted certiorari and upheld the Ninth Circuit opinion insofar as it held that the California notice-prejudice rule was saved as a state rule regulating insurance. ${ }^{49}$ The Court determined that it was unnecessary that a rule meet all of the McCarran-Ferguson factors in order to regulate the business of insurance and be saved from preemption. ${ }^{50}$ The Court found that the notice-prejudice rule was

43 Id at 1279.

44 Id at $1286-89$.

45 Id at $1280-81,1289$.

46 Id at 1280.

47 Id at 1289.

48 Id at $1280-81,1289$.

49 Ward, 526 US at 373.

50 The Court in Ward determined that the McCarran-Ferguson factors are "considerations to be weighed ... and none is necessarily determinative in itself." Id at 360, quoting Pilot Life Insurance Co v Dedeaux, 481 US 41, 49 (1987), and Union Labor Life Insurance Co v Pireno, 458 US 119,129 (1982). However, whether or not a law is aimed at the insurance industry (the third McCarran-Ferguson factor) seems to carry more weight than the other two. See Ward, 526 US at 373-74 (holding that California's notice-prejudice rule is saved from preemption because it serves as an integral part of the insurance relationship (factor two) and is aimed at the insurance industry (factor three) without an analysis of the Ninth Circuit's prior determination that the notice-prejudice law did not in fact satisfy the "risk-spreading" factor (factor one)). Ward did not argue that the employer agency rule was saved from preemption before the Supreme Court; 
saved because it served as an "integral part of the policy relationship between the insurer and the insured" and "[t]he rule "does not merely have an impact on the insurance industry; it is aimed at it.",52

However, the Supreme Court reversed the Ninth Circuit's determination that the state's agency rule was not preempted. ${ }^{53}$ By so doing, the Court determined that California's agency laws pertaining to the agency relationship of employer-administrators were preempted by ERISA. ${ }^{54}$ In its determination that the California agency rule "related to" ERISA plans, the Court concentrated on the impact of the California rule on plan administration. ${ }^{55}$ The Court determined that the agency rule "would force the employer, as plan administrator, to assume a role, with attendant legal duties and consequences, that it has not undertaken voluntarily." The Court concluded: "Satisfied that the Elfstrom rule 'relates to' ERISA plans, we reject the Ninth Circuit's contrary determination."

Without an agency rule, federal courts will necessarily defer to whatever contractual terms the employer and insurer have agreed upon. ${ }^{58}$ Insurers and employers will often contract out of liability (at the expense of the employee) by having the employer serve as plan administrator. ${ }^{59}$ After Ward, federal courts must choose whether they wish to allow the contractual terms between the employer and the insurer to govern regardless of the effect on the employee's interests, or whether they will craft a federal common law rule giving effect to ERISA's statutory goal of protecting plan beneficiaries.

since the rule grew out of general principles of the common law of agency, prior Supreme Court decisions would deem the rule not saved. Pilot Life Insurance Co, 481 US at 51 (holding that state laws developed from general common law principles are not saved).

51 Ward, 526 US at 374, citing Metropolitan Life Insurance Co v Massachusetts, 471 US 724, 743 (1985).

52 Ward, 526 US at 375, quoting FMC Corp v Holliday, 498 US 52, 61 (1990).

53 Ward, 526 US at 378-79.

54 Id. Preemption of state law without replacement in this case removes half a century of legal evolution. See discussion of the Boseman rule in Parts III.A and III.D.1.

55 Ward, 526 US at 379 (holding that "deeming the policyholder-employer the agent of the insurer would have a marked effect on plan administration").

56 Id.

57 Id (citation omitted).

58 See Torello v UNUM Life Insurance Co of America, 1999 US App LEXIS 32228, *12-13 (6th Cir) (relying on contract terms between employer and insurer in the absence of an agency relationship).

59 See id. See also text accompanying note 71.

6029 USC § 1001(a) (1994) ("[I]t is desirable in the interests of employees and their beneficiaries ... that minimum standards be provided assuring the equitable character of [retirement] plans and their financial soundness."). See also Zanglein, 72 Wash U L Q at 671-72 (1994) (cited in note 4) (discussing the need for federal common law rules to replace those remedies preempted by ERISA). 
C. The Aftermath of Ward: An Opportunity for the Development of a Federal Common Law of Employer Agency

The Supreme Court's opinion in Ward leaves open the possibility of adopting a federal common law rule of agency for employeradministrators. The Court determined that the state agency rule was preempted, ${ }^{61}$ but it did not make a determination regarding the adoption of a rule as a matter of federal common law.

The question of federal common law adoption therefore remains unresolved. The Ninth Circuit had been requested to adopt the Elfstrom approach as federal common law if it found the rule preempted. ${ }^{62}$ The Ninth Circuit reserved this question for a later date, finding instead that the Elfstrom rule was not preempted by ERISA. ${ }^{63}$

The question of federal common law adoption of a rule of agency was raised again before the Supreme Court. ${ }^{54}$ The Solicitor General suggested remand to the Ninth Circuit to decide whether "the Elfstrom rule, or something like it" should be adopted as the federal common law standard. ${ }^{65}$ The Court did not rule on this issue, resolving the case instead on its determination that California's notice-prejudice rule was saved as a state law "regulating insurance."

Cases subsequent to Ward show a gap in the law that will considerably impede beneficiaries from recovering plan benefits. ${ }^{67}$ A considerable number of states have adopted rules allowing beneficiaries to recover via agency. ${ }^{66}$ However, in Torello v UNUM Life Insurance Co of America, ${ }^{69}$ as one example, the Sixth Circuit held that Ohio's agency rule was simply preempted, citing Ward:

61 Ward, 526 US at $367 \mathrm{n} 1$ ("Common-law rules developed by decisions of state courts are 'State law' under ERISA."), citing 29 USC $\$ 1144$ (c)(1) (1994) ("The term 'State law' includes all laws, decisions, rules, regulations, or other State action having the effect of law.").

62 See Ward, 135 F3d at 1281, 1284.

63 Id at 1289.

64 Brief for the United States as Amicus Curiae Supporting Petitioner in Part and Supporting Respondent in Part *7, UNUM Life Insurance Co of America v Ward, No 97-1868 (filed Nov 27,1998 ) (available on Lexis at 1997 U.S. Briefs 1868) ("The Elfstrom rule is not saved by the insurance savings provision.... A federal court in a case like this could, however, apply similar agency principles as a matter of federal common law under ERISA.").

65 Id at *28 (suggesting that the case be remanded for the Ninth Circuit to decide whether the Elfstrom rule applies "as a matter of federal, not California, common law").

66 Ward, 526 US at 364.

67 See, for example, Torello v UNUM Life Insurance Co of America, 1999 US App LEXIS $32228, * 13$ (6th $\mathrm{Cir}$ ) (denying employee recovery due to contract shielding employer from the breach of fiduciary duty claim).

68 Following the demise of general federal common law in Erie Railroad Co $v$ Tompkins, 304 US 64, 79-80 (1938), this area of law has been exclusively developed by state law. See note 90 for a list of states providing such protection.

691999 US App LEXIS 32228 (6th Cir). 
We find that G\&J Bottlers did not serve as an agent for UNUM. The long-term disability insurance policy contains a provision that explicitly states G\&J Bottlers is not UNUM's agent. Even if Ohio law provided otherwise, a state law that purports to make a policyholder-employer an agent of an insurer is preempted by ERISA. In the absence of an agency relationship between G\&J Bottlers and UNUM, any notice Torello may have provided to G\&J Bottlers is of no moment. ${ }^{70}$

Without a federal common law agency rule governing actions taken by employer-administrators, plan beneficiaries will often lack any remedy."

Moreover, in many instances insurers will also suffer because of the gap created by preemption. A sophisticated agency rule will make the employer-administrator the agent of the employee when their interests are aligned (as in contract negotiation settings). ${ }^{72}$ If state employer-agency laws are preempted without replacement, insurers will not be able to rely on the assumption that employers are acting as agents for the employees in contract negotiation settings.

\section{The Thomason Discussion: When Should Courts Adopt State Rules as a Matter of Federal Common Law?}

The Seventh Circuit has proposed a framework within which courts should adopt state rules as federal common law to fill gaps in ERISA. ${ }^{74}$ First, ERISA itself must "not expressly address the issue before the court." Second, while state common law may serve "as a basis for new federal common law," development of federal common law must be consistent with the congressional "policies underlying ERISA." Courts may therefore use state-developed rules as federal common law, "but only to the extent that state law is not inconsistent with congressional policy concerns.",

70 Id at $* 13$ (citations omitted).

71 See Zanglein, 72 Wash U L Q at 674 (cited in note 4) ("The participant is caught in the vortex of an ever-expanding preemptive black hole, unregulated by ERISA, and unprotected by state law.").

72 See Boseman v Connecticut General Life Insurance Co, 301 US 196, 204-05 (1937) (listing insurance-related tasks completed by employer when not acting as an agent of the insurer).

73 See Jones v Benefit Trust Life Insurance Co, 605 F Supp 179, 183 (S D Miss 1985) (holding that employee did not delegate negotiating authority to employer for negotiations with insurer), affd in part, vacated in part, $800 \mathrm{~F} 2 \mathrm{~d} 1397$ (5th Cir 1986).

74 Thomason v Aetna Life Insurance Co, 9 F3d 645, 647 (7th Cir 1993) (holding that state rules may be used as a basis for new federal common law rules under ERISA only if they comport with Congress's intent regarding the statute).

75 Id, quoting Nachwalter v Christie, 805 F2d 956, 959 (11th Cir 1986). See also Zanglein, 72 Wash U L Q at 716 (cited in note 4) (citing Thomason for the same proposition).

76 Thomason, 9 F3d at 647.

77 Id. 
The first prong is easily met; there is no agency rule set forth in ERISA. As to the second, the relevant congressional policy concerns are (1) the protection of beneficiaries, ${ }^{78}$ and (2) that remedies available before the enactment of ERISA should not be removed simply because ERISA does not explicitly mention them. ${ }^{79}$ To these ends, Congress stated explicitly that courts were to supplement ERISA with federal common law. ${ }^{80}$ The question remaining is which, if any, of the existing state rules best provides remedies that adequately protect beneficiaries' interests. At least three possible state rules could be adopted. The majority rule among the states designates the employer the agent of the employee both when negotiating a contract with the employer and later when administering the plan. ${ }^{81}$ The minority approach would designate the employer the agent of the insurer. ${ }^{82}$ The integrated approach makes a fact-specific determination of whether the employer was acting on behalf of the insurer or the employee. These rules, and criteria courts might employ in choosing among them, are discussed in more detail below.

\section{THE OPTIONS: MAJORITY, MINORITY, AND INTEGRATED RULES OF EMPLOYER AGENCY}

\section{A. The Majority Rule: Boseman v Connecticut General Life Insurance $\mathrm{Co}^{84}$}

Federal courts should overcome their hesitancy toward creating a federal common law of employer agency pursuant to ERISA. They

7829 USC $\$ 1001 \mathrm{a}(\mathrm{c})(3)$ (1994). See also Zanglein, 72 Wash U L Q at 674 (cited in note 4) (noting "ERISA's stated goal of safeguarding the rights of plan participants").

79 See Firestone Tire \& Rubber Co v Bruch, 489 US 101, 114 (1989) (rejecting interpretation "that would afford less protection to employees and their beneficiaries than they enjoyed before ERISA was enacted"). See also Sanson v General Motors Corp, 966 F2d 618, 623 n 2 (11th Cir 1992) (Birch dissenting) ("I do not subscribe to the view that for every wrong there must necessarily be a remedy. However, where there is a remedy ... I find it difficult to comprehend, in a common sense way, how a law enacted to protect the very class of individuals into which the appellant squarely fits can be construed to deny him such a preexisting remedy.").

80 See Recommendation Report, HR Rep No 101-247 at 56 (cited in note 9) ("Congress intended for the courts to develop a Federal common law with respect to employee benefit plans, including the development of appropriate remedies, even if they are not specifically enumerated in ... ERISA."). See also notes 7-9, 26-30, and accompanying text.

81 See note 90 for a list of majority rule jurisdictions.

82 See note 93 for a list of minority rule jurisdictions.

83 See, for example, Golt v Aetna Life Insurance Co, 2000 Mont 155, 2 P3d 841, 849 (2000) (holding that employer, in administering the insurance plan, acts as agent of the insurer); Dawes Mining Co v Callahan, 246 Ga 531, 272 SE2d 267, 269 (1980) (same); Norby v Bankers Life Co, 304 Minn 464, 231 NW2d 665, 669 (1975) (same); Paulson v Western Life Insurance Co, 292 Or 38, 636 P2d 935 (1967) (same). See also note 93 for a list of integrated rule jurisdictions. The Comment treats integrated cases as a subset of the minority rule cases.

84301 US 196, 204-05 (1937) (holding that employer-administrators act as the agents of employees when negotiating a contract or administrating a plan). 
had, in fact, already begun to develop law on the topic as a matter of general federal common law prior to Erie Railroad Co v Tompkins. ${ }^{85}$ In 1937 the Supreme Court issued an opinion in Boseman v Connecticut General Life Insurance $\mathrm{Co}^{86}$ that set forth the following rule: "[w]hen procuring the policy, [and] obtaining applications of employees ... employers act not as agents of the insurer but for their employees or for themselves." Although the "employer as agent of the employee" rule, set forth in Boseman, sought to determine the agency of an employer engaged in contract negotiations (and not in employeradministrator situations), ${ }^{88}$ it supports the proposition that agency determinations regarding employers are desirable and necessary as a matter of federal common law.

Boseman in and of itself is no longer good law, since the Erie Court determined that federal courts may not develop general federal common law. However, during the period in which federal courts lacked authority to speak on the subject, Boseman was often emulated by the state rules that replaced it (and that are now preempted by ERISA), and it is now considered the majority rule among the states.

85304 US 64 (1938).

86301 US $196(1937)$.

87 Id at 204-05.

88 Id.

89 Erie, 304 US at 78 (stating that "[t]here is no federal general common law"). See also Sampson v Channell, 110 F2d 754, 761 (1st Cir 1940) ("Under Swift v. Tyson ... the federal courts were free to disregard state court decisions on matters of 'general law' .... But under [Erie] the [state] law must be determined by the state statutes and the common law as interpreted by the state courts, not by the federal court's notion of 'general law."').

90 The following states have either adopted the Boseman rule or have adopted rules that have the same effect. Alabama: Blue Cross-Blue Shield of Alabama v Fowler, 43 Ala App 572, 195 S2d 910,914-15 (1966); but see All States Life Insurance Co v Tillman, 226 Ala 245, 146 S 393, 396 (1933) (without discussing agency, determining that employer error did not terminate employee's insurance); Arkansas: Hendrix v Republic National Life Insurance Co, 270 Ark 955, 606 SW2d 601, 603 (1980); Connecticut: Emerick v Connecticut General Life Insurance Co, 120 Conn 60, 179 A 335, 338 (1935); Florida: Couch v Connecticut General Life Insurance Co, 216 S2d 72, 74 (Fla App 1968); Illinois: Phelps v Elgin Academy, 125 Ill App 2d 364, 260 NE2d 864, 867 (1970); but see Patterson v John Hancock Mutual Life Insurance Co, 27 Ill App 135, 169 NE2d 183, 187 (1960) (illustrating limited circumstances under which employer is insurer's agent); Indiana: Hayes v Lincoln General Insurance Co, 899 F2d 684, 686 (7th Cir 1990) (applying Indiana state law); Kansas: Leach v Metropolitan Life Insurance Co, 124 Kan 584, 261 P 603 (1927); Kentucky:

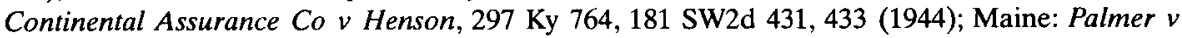
Newport Trust Co, 245 A2d 438, 441-42 (Me 1968) (holding that a bank is the agent of the insured when remitting premiums); Michigan: Barza v Metropolitan Life Insurance Co, 281 Mich 532, 275 NW 238, 241 (1937); New Hampshire: Duval v Metropolitan Life Insurance Co, $82 \mathrm{NH}$ 543, 136 A 400, 403-05 (1927); New Jersey: Mosior v Insurance Co of North America, 193 NJ Super 190, 473 A2d 86, 89 (1984); New York: Estock v Associated Hospital Service of New York, Inc, 257 NYS2d 559, 45 Misc 2d 504, 505 (Civ Ct 1964) (holding failure of employer to forward insurance certificate to employee could not stop insurer from asserting two year statute of limitations); Fidelity \& Casualty Co v Metropolitan Life Insurance Co, 248 NYS2d 559, 42 Misc 2d 616, 631 (Sup Ct 1963) (holding that employer stands in shoes of employee when he contracts for group insurance); Ohio: Hroblak v Metropolitan Life Insurance Co, 50 Ohio L Abs 395, 79 NE2d 
Since Boseman, however, other states have developed contrary rules that better serve the purposes of ERISA and are therefore better suited for adoption."

\section{B. The Minority Approach}

1. Development of the minority approach among the states.

One alternative approach to employer agency first encourages courts to examine

"the way group insurance is set up and operated ... [and then to determine whether] the employer should be charged with the performance of certain functions on behalf of the insurance company," rather than resolve first the agency question and then decide whether the employer is charged with some functions on behalf of the insurer. ${ }^{92}$

The unmistakable trend in recent cases has been to adopt the minority rule (employer is agent of the insurer) or the integrated approach, which makes a fact-specific determination of the employer's role. ${ }^{93}$ In-

360, 364 (App 1947); Pennsylvania: Layman v Continental Assurance Co, 416 Pa 155, 205 A2d 93, 95-96 (1964); Hanaieff v Equitable Life Assurance Society, 371 Pa 560, 92 A2d 202, 204-05 (1952); Tennessee: Tibbs v Equitable Life Assurance Society of the United States, 179 Tenn 594, 168 SW2d 779 (1943); Texas: Johnson v Johnson, 139 F2d 930, 934 (5th Cir 1943) (applying Texas law); but see Missouri State Life Insurance Co v Compton, 73 SW2d 1079, 1086 (Tex Civ App 1934) (holding payment by employee through salary deduction by employer was payment to the insurer); Utah: Sorenson v Hartford Accident and Life Insurance Co, 585 P2d 440, 441 (1978); West Virginia: South Branch Valley National Bank v Williams, 151 W Va 775, 155 SE2d 845, 849 (1967). The federal courts have also adopted such a rule for local District of Columbia cases. Metropolitan Life Insurance Co $v$ Ross, 1976 US Dist LEXIS 11840 at *7 (D DC).

See 43 Am Jur 2d Insurance $\S 110$ (1982) ("[E]mployers, in doing the various acts required to make effective a policy of group insurance covering employees ... act for themselves and their employees, and not as agents of the insurer.") (citing Boseman); John A. Appleman and Jean Appleman, 1 Insurance Law and Practice $\$ 43$ at 89 (West 1981 \& Supp 1992); John A. Appleman and Jean Appleman, 16 Insurance Law and Practice $\S 8734$ at 390 (West 1981 \& Supp 1992). See 22 ALR 4th $321 \S \S 10,14-15$ (1983 \& Supp 1999), for a state by state list of responses to the closely related problem of whether an employee's coverage terminates due to the employer's failure to remit premiums.

91 See 29 USC $\$ 1001 \mathrm{a}(\mathrm{c})(3)$ (1994) (describing Congress's intent to provide reasonable protection to plan beneficiaries as among the primary purposes of ERISA).

92 Sadtler v John Hancock Mutual Life Insurance Co, 291 A2d 500, 502 (DC App 1972), quoting Eugster, Comment, 46 Wash L Rev at 407 (cited in note 37).

93 The following states have adopted the minority rule or have adopted a contextdependent approach to determining when an employer is the agent of an insurer. Note that the "minority approach" is no longer appreciably in the minority, and is followed by the majority of modern decisions. California: Elfstrom, 432 P2d at 737; Colorado: New York Life Insurance Co v Love, 163 Colo 7, $428 \mathrm{P} 2 \mathrm{~d} 364,366$ (1967) (holding that payment by the insured to the employer is payment to the insurer); Georgia: Dawes Mining Co v Callahan, $246 \mathrm{Ga} 531,272$ SE2d 267, 269-70 (1980); Clements v Continental Casualty Insurance Co, 730 F Supp 1120, 1123-24 (N D Ga 1989) (applying Georgia law); Iowa: Freeman v Bonnes Trucking, Inc, 337 NW2d 871, 874-75 (Iowa 1983); Louisiana: Neider v Continental Assurance Co, 213 La 621, 35 S2d 237, 240-41 
sofar as this developing strand of case law is concerned, three cases are of particular interest: Elfstrom v New York Life Insurance Co, Paulson $v$ Western Life Insurance Co, ${ }^{95}$ and the Ninth Circuit's decision in Ward $v$ Management Analysis Co Employee Disability Benefit Plan.

\section{The Elfstrom rule: Employer as agent of the insurer.}

The most straightforward minority approach is that espoused by Elfstrom itself. Under a pure Elfstrom rule, the employer is simply considered an agent of the insurer when managing a group insurance plan. ${ }^{97}$ The Elfstrom court understood the reasoning behind the Boseman line of cases: "The rationale of these cases appears to be that the employer is acting for its own benefit or for its employees in perform-

(1948); Massachusetts: Kirkpatrick v Boston Mutual Life Insurance Co, 393 Mass 640, 473 NE2d 173, 176-78 (1985); Clauson v Prudential Insurance Co, 195 F Supp 72, 80 (D Mass 1961) (applying Massachusetts law), affd 296 F2d 76 (1st Cir 1961) (applying Massachusetts law); Minnesota: Norby v Bankers Life Co, 304 Minn 464, 231 NW2d 665, 668-69 (1975); Mississippi: Home Life Insurance Co $v$ Chandler, 402 S2d 356, 359-60 (Miss 1981) (citing Boseman, but making a factspecific determination); Missouri: First National Bank $v$ Farmers New World Life Insurance Co, 455 SW2d 517, 521-22 (Mo App 1970) (holding against agency in the particular case but using a case-by-case approach to determine employer agency overall); Montana: Golt v Aetna Life Insurance Co, 2000 Mont 155, 2 P3d 841, 848-49; North Carolina: Middleton v Russell Group, Ltd, 126 NC App 1, 483 SE2d 727, 733-34 (1997), affd after remand, 132 NC App 792, 514 SE2d 94 (1999); North Dakota: Finstad v Steiger Tractor, 301 NW2d 392, 395-96 (ND 1981); Oklahoma: Baum v Massachusetts Mutual Life Insurance Co, 357 P2d 960, 964 (Okla 1960); Oregon: Paulson $v$ Western Life Insurance Co, 292 Or 38, 636 P2d 935, 939-40 (1967); South Carolina: Weeks v Pilot Life Insurance Co, 256 SC 81, 180 SE2d 875, 877-78 (1971) (holding that an employer deducting insurance premiums from an employee's wages was the agent of the insurer); Vermont: $A b$ biati v Buttura \& Sons, 161 Vt 314, 639 A2d 988, 993 (1994); Wisconsin: Kaiser v Prudential Insurance Co, 272 Wis 527,76 NW2d 311,315 (1956).

The following states have adopted rules to solve the problem of employer-administrator misconduct without express statement of agency. Alabama: All States Life Insurance Co $v$ Tillman, 226 Ala 245, 146 S 393, 393-94 (1933) (holding that although nonagency provision is valid, employer-deducted premiums are attributed to insurer); Delaware: Bureau of Adult Correction v Dernberger, 1987 Del Super LEXIS 1059, *5-6 ("Where medical bills are submitted to the employer in a timely fashion. ... claimant should not be prejudiced by the erroneous act of the employer or its carrier ...").

The following states have not addressed the issue of employer agency in the insurance context: Alaska, Arizona, Hawaii, Idaho, Nebraska, Nevada, New Mexico, Maryland, Rhode Island, South Dakota, Virginia, Washington, and Wyoming.

States now addressing or reassessing the issue are likely to follow the modern trend toward the minority fact-specific approach. See, for example, Golt, 2 P3d at 841 . The above cases obviously overlap with cases determining whether the failure of an employer to remit premiums terminates the insurance of the employee (regardless of agency theories). See 22 ALR 4th 321 $\$ \S 10,13-14$ at $344,350-54$ (cited in note 90 ) (treating issue on a state-by-state basis); John A. Appleman and Jean Appleman, 1a Insurance Law and Practice $\S 352,427-35$ (West 1981) (same).

\footnotetext{
$94432 \mathrm{P} 2 \mathrm{~d} 731$.

$95 \quad 636 \mathrm{P} 2 \mathrm{~d} 935$

$96 \quad 135$ F3d 1276 (9th Cir 1998).

97 Elfstrom, $432 \mathrm{P} 2 \mathrm{~d}$ at 737.
} 
ing these tasks ... that the employer and the employees are allied in their interests, and that these interests are adverse to the insurer.", However, the Elfstrom court chose to reject the Boseman rule for the employer-administrator setting, pointing out that "the employer carries out the functions which the insurer necessarily would perform in other types of insurance." about the difficulties inherent in employee loss of benefits because of the employer-manager's errors, which would occur under the Boseman rule. The court stated: "[S]ince the individual employee has no knowledge of or control over the administrative acts performed by the employer, it would be inequitable to charge him with the employer's errors."

The Elfstrom court found the employee's lack of control over the employer in negotiating and handling the insurance dispositive of the fact that, ultimately, the employer is the insurer's agent. ${ }^{101}$ Note that although the Elfstrom rule offers plan beneficiaries critical protection against employer-administrator misconduct, it also impedes situations where employees would legitimately be expected to delegate authority to negotiate a contract.

\section{The integrated approach.}

In Paulson, ${ }^{103}$ the Oregon Supreme Court adopted an approach that integrated the majority approach, as followed by Bowes v Lakeside Industries, Inc, ${ }^{104}$ with the minority rule. ${ }^{105}$ The Paulson court held that the question of whether an employer was the agent of an insurer or the insured was not a matter of adopting either standard but rather a determination of fact:

\section{Id.}

99 Id.

100 Id. See also Jones v Benefit Trust Life Insurance Co, 605 F Supp 179, 182 (S D Miss 1985) (discussing the Boseman principle).

101 The court reasoned:

The most persuasive rationale for adopting the view that the employer acts as the agent of the insurer [ ] is that the employee has no knowledge of or control over the employer's actions in handling the policy or its administration. An agency relationship is based upon consent by one person that another shall act in his behalf and be subject to his control.

$432 \mathrm{P} 2 \mathrm{~d}$ at 738 .

102 See Part III.D.2.

$103636 \mathrm{P} 2 \mathrm{~d} 935$.

104297 Minn 86, 209 NW2d 900 (1973).

105 Paulson, 636 P2d at 941 ("It appears to us that Elfstrom and Bowes are neither inconsistent with each other nor do they reflect the application of different rules."). See also Dawes Mining Co v Callahan, 246 Ga 531, 272 SE2d 267, 269 (1980) (constructing a dividing line between contract negotiation settings, where the employer is not the agent of the insurer, and later administration settings, where the court deemed the employer the agent of the insurer). 
Our analysis of the decisions convinces us that many courts, even though they purport to apply a "majority rule" or a "minority rule," actually base their decision upon the facts relating to the division of functions between the insurer and the employerpolicyholder, and that any "majority" or "minority" rule is more apparent than real. ${ }^{106}$

In Paulson, the Court compared the Elfstrom result to the majority rule. $^{107}$ It noted that the primary difference between the approaches was their characterization of the degree of autonomy exercised by the employer in plan administration. ${ }^{108}$ In Elfstrom, the plan was deemed "employer administered" because the insurer had "delegated extensive duties to the employer, including enrolling employees, adding and deleting dependents, terminating and reinstating insurance, reporting details of coverage, indicating the amounts of premiums paid, issuing certificates of insurance, and determining eligibility for coverage.", However, majority rule jurisdictions had characterized the employer as a mere "supplier of information," in contrast to the full-service employer-administrator of Elfstrom.

On the basis of this fact-sensitive analysis, the Oregon Court found that the majority and minority approaches both drew on the same rule: "In the performance of a function delegated by the insurer to the employer, the employer is deemed to be the agent of the insurer." Since this Paulson approach is consistent with Boseman, yet incorporates the evolution of the law since that time, this integrated rule should be adopted by federal courts as a matter of federal common law under ERISA.

The Ninth Circuit, when deciding Ward, drew heavily on Paulson. ${ }^{112}$ The Ninth Circuit adopted the Paulson "question of fact" test as consistent with and an improvement on the Elfstrom rule: "The Paulson formulation of the Elfstrom rule appears sound. It also comports with our prior determination of the same issue." ${ }^{113}$ Since the Ninth Circuit reserved the question as to whether this employer-agency standard would be adopted as a matter of federal common law, it is entirely possible that the Ninth Circuit would adopt a Paulson integrated approach as a federal common law rule."

$106636 \mathrm{P} 2 \mathrm{~d}$ at 939.

107 Id at 940, analyzing Bowes, 209 NW2d at 900.

108 Paulson, $636 \mathrm{P} 2 \mathrm{~d}$ at 941.

109 Id at 941, quoting Bowes, 209 NW2d at 901-02.

110 Paulson, $636 \mathrm{P} 2 \mathrm{~d}$ at 941, quoting Bowes, $209 \mathrm{NW} 2 \mathrm{~d}$ at 902. See also Dawes Mining Co, 272 SE2d at 269.

111 Paulson, 636 P2d at 941.

112 Ward, 135 F3d at 1281-83 (specifically considering Paulson's treatment of Elfstrom).

113 Id at $1283 \mathrm{n} 6$.

114 See Part II.C for a discussion of the Ninth Circuit's treatment of federal common law 
In Jones v Benefit Trust Life Insurance $C o,{ }^{115}$ a federal court had a rare opportunity to voice its own determinations regarding the evolution of employer-agency rules. The Mississippi Supreme Court's interpretive abstinence on the issue ${ }^{116}$ opened the door for the Jones court to adopt a fact-sensitive approach rather than either of the hard and fast rules."

The Jones court was asked to determine whether an insurer had a duty to inform the employee of any negotiated changes in the plan, or whether the knowledge of the employer could be imputed to the employee as principal. ${ }^{118}$ The Jones court was troubled by the fact that the employee had no real representation at policy negotiations, and concluded that the employee had not delegated negotiating power. ${ }^{19}$ The Jones decision is revealing because the court cited Boseman, which found agency as the majority rule, but nevertheless found on the facts of the case that the employer was not the agent of the employee when negotiating the policy. ${ }^{120}$ This outcome lends credence to the suggestion that federal courts will act as state courts have in making fact-specific determinations based on the nature of the action undertaken by the employer-agent. ${ }^{121}$

\section{The federal common law of employer agency.}

Federal courts should follow the congressional mandate and develop a federal common law of agency pursuant to ERISA. The Supreme Court held that Congress expressly conferred the authority to do so on the federal judiciary. ${ }^{122}$ Given the changes in the law since Boseman and the statutory purposes of ERISA, federal courts should further develop a federal common law of employer agency.

adoption of the Elfstrom rule.

$115605 \mathrm{~F}$ Supp 179, 183 (S D Miss 1985) (holding that changes in an insurance policy communicated only to an employer do not constitute constructive notice to an employee).

116 Home Life Insurance Co v Chandler, 402 S2d 356, 360 (Miss 1981) (holding that "it is not necessary for this Court now to make a choice between the opposite position held by the various states" regarding employer agency in insurance cases).

117605 F Supp at 182-83, citing with approval the case-by-case approach of the Mississippi Supreme Court in Home Life Insurance Co, 402 S2d at 356.

118605 F Supp at 182-83 (adopting a fact-sensitive standard and determining that an employer could not be considered the agent of the employee for purposes of information communicated only to the employer).

119 Id at 183. Compare Elfstrom, $432 \mathrm{P} 2 \mathrm{~d}$ at 738 (finding that the employer/employee relationship at issue "fail[ed] to reflect true agency" due to the employee's lack of knowledge regarding, or control over, the "employer's actions in handling the policy or its administration").

120605 F Supp at 182.

121 For a counterexample, see Metropolitan Life Insurance Co v Ross, 1976 US Dist LEXIS 11840 at * 7 (D DC).

122 See notes $7-10$. 
Which rule they should articulate, however, remains open for discussion. The following discussion addresses first whether there is a need for a rule of employer agency, and then argues that policy considerations, statutory statements of ERISA's purpose, and congressional intent as expressed in legislative history all support adopting the Paulson integrated rule for employer agency over the alternatives.

\section{Is an Agency Rule Necessary to Fulfill the Purposes of ERISA?}

1. Without federal common law, insurers avoid liability that they would normally bear.

Without a federal common law rule of agency, employers and insurers will be able to contract their way out of vicarious liability, leaving beneficiaries with no protection in situations where the employer misbehaves or makes a mistake. ${ }^{123}$ If the insurer had administered the plan, or had hired third party administrators who acted on the insurer's behalf, mistakes or fraud by these administrators would be attributable to the insurer. ${ }^{124}$ It is for this reason that agency law is largely based on the facts of the relationship between the parties rather than their contract: ${ }^{125}$ one can imagine the problems that would result if employees and employers were allowed to contract out of respondeat superior liability to injured third parties. ${ }^{126}$ The fact-sensitive Paulson rule would respond to this difficulty, making the agency determination based on the actions of the parties rather than their contract.

2. Preemption without replacement creates no incentive for insurers to monitor, inform, or guide plan administrators.

Preempting state agency laws without replacing them also creates serious problems of incentives for insurers. Without an agency rule, insurers will have less incentive to check that an employer is competent to manage a plan, since they will not bear liability for the employer's

123 See Elfstrom, $432 \mathrm{P} 2 \mathrm{~d}$ at 737.

124 Id.

125 See 2A Corpus Juris Secundum Agency \& 7 (1972):

Whether as between the parties their relationship is one of agency depends on their relations as they in fact exist under the ... acts of the parties, and the question is not governed by the stipulations of the parties. Thus, whether a particular relationship is that of agency does not depend on what the parties call it, and the parties cannot, where the relationship is in fact one of agency, change its nature by declaring that it is not an agency.

(citations omitted) (emphasis added).

126 See Note, An Efficiency Analysis of Vicarious Liability Under the Law of Agency, 91 Yale L J 168, 184 (1981) ("[T]he absence of vicarious liability affords the principal and the agent an opportunity to execute an optimal judgment-proof contract, which leaves the agent insolvent in the accident state of nature, and which partially evades the tort victim's right to compensation."). 
incompetence. For the same reasons, insurers will have little incentive to monitor ongoing administration, or to make sure that new information (such as negotiated changes in plan coverage) reaches the beneficiaries.

On the other hand, lower administrative costs will likely result in lower premiums paid by the employees, and therefore the benefit of employer plan administration will be passed on to the plan participants. On balance, however, this argument is weak because plan participants are unlikely to assess correctly the risk of administrator fraud. ${ }^{127}$ The essence of fraud is misinforming the victim as to the trustworthiness of the perpetrator, here the employer-administrator. Given this, plan participants will underestimate the risk and be systematically undercompensated (via lower premiums) for their assumption of the risk of administrator misconduct. ${ }^{12}$

Still, perhaps specific knowledge of the trustworthiness of the particular administrator is not necessary, since an assessment of the overall risk of employer fraud, if shouldered by the employee, might produce a reduction in the premiums. But again, the employee will be at a systematic disadvantage for several reasons. First, while the insurer will be a repeat player (and might have access to data indicating the proper risk of employer misconduct), the employee almost certainly will not. Second, and more importantly, the employee will almost never be the party negotiating the benefits contract with the insurer. ${ }^{129}$ The employer will not negotiate effectively for the risk of his own dishonesty or incompetence. The employee will again be undercompensated for the risk of employer misconduct. ${ }^{130}$ Third, the market

127 See Paul C. Weiler, Governing the Workplace: The Future of Labor and Employment Law 15-22 (Harvard 1990) (discussing the uses and limits of the market in protecting employees).

128 See Amos Tversky and Daniel Kahneman, Judgment Under Uncertainty: Heuristics and Biases, 185 Science 1124, 1127 (1974) (discussing problems of information differentials and processing in decisionmaking).

129 See Clements $v$ Continental Casualty Insurance Co, 730 F Supp 1120, 1124-25 (N D Ga 1989), for an analysis of the difference between contract negotiation settings and plan administration settings with respect to the power held by the employee. Because the employee does not know more than the list of benefits to which he is entitled, "[h]e does not ask whether the insurance plan is 'insurer-administered' or 'employer-administered.' He may reasonably assume that his employer and the insurer will, in their dealings with each other, do that which is necessary to provide him with the promised benefits." Id (emphasis added). An agency rule that mimics the employee's reasonable assumption is therefore desirable. Id. Employees also suffer from collective action problems in bargaining relative to employers. See Louise Sadowsky Brock, Note, Overcoming Collective Action Problems: Enforcement of Worker Rights, 30 U Mich J L Ref 781, 782-83 \& n 11 (1997) (arguing that collective action problems "prevent[ ] workers from taking effective individual action ... because any benefit they gain will be shared by all employees").

130 Dayna Bowen Matthew, Controlling the Reverse Agency Costs of Employment-Based Health Insurance: Of Markets, Courts, and a Regulatory Quagmire, 31 Wake Forest L Rev 1037, 1039 (1996) ("The task of controlling and monitoring the employer-agent's decisions and choices for their employees is monumental."); id at 1061 ("It is almost impossible for employees, in the 
will not adequately compensate employees for their increased risk of loss because most employees do not shop around for the best insurance deal-they take the package that is handed to them by their employer. $^{131}$

Finally, even absent the disparities in information and bargaining power between insurers and employees, it seems clear that the insurer is the party best situated to absorb the risk of loss. ${ }^{132}$ Insurers are likely to identify risky employers and raise rates accordingly. Insurers can (and will) pass those costs on to all policyholders, spreading the risk across the client base. On this account, an insurance company can spread risks and largely be unaffected by a loss that would cripple an individual employee.

\section{The Paulson integrated approach to agency fulfills the expectations of plan beneficiaries.}

Legal commentators have developed a standard for ERISA federal common law development that protects "the reasonable expectations of plan participants." ees) have an expectation that they will receive their benefits if they make their payments, provide notice, and perform their other duties under the insurance contract. ${ }^{134}$ This expectation is betrayed by a regime that denies their claims for benefits because of an employeradministrator's misconduct or mistake. ${ }^{1.35}$ Preemption without replacement therefore undermines the expectations of plan beneficiaries who have fully complied with their insurance contract requirements.

Adopting the fact-sensitive approach of the Paulson rule might better comport with this standard by giving weight to the expectations of plan participants. When an employer acts as a full-service administrator, employees will consider their obligations under the contract to

majority of cases, to engage in ex ante monitoring of their employer-agent's purchase of insurance.").

131 See id at 1042 ("As of 1993, 145 million, or 58.5\% of Americans were covered by employer-based health insurance policies.").

132 Insurance companies spread risks by trade. See 43 Am Jur $2 d$ Insurance $\$ 188$ (1982) (defining "insurer" as the party who "assumes the risk and undertakes to indemnify the insured").

133 George Lee Flint, Jr., ERISA: Reformulating the Federal Common Law For Plan Interpretation, 32 San Diego L Rev 955, 1047 (1995).

134 See Norby v Bankers Life Co, 304 Minn 464, 231 NW2d 665, 668-69 (1975) ("It is [] unreasonable and inequitable to frustrate the employee's expectations because of an employer's negligence in administering the insurance agreement.").

135 The possibility of suit against the employer is insufficient to protect beneficiaries. See note 38 .

136 See Zanglein, 72 Wash U L Q at 671-76 (cited in note 4) (discussing the problems of "betrayal without remedy"). 
be discharged by notification of injury or remittance of premiums to the plan administrator. ${ }^{137}$ A rule that determines that these obligations are actually discharged because of an agent-principal relationship between the employer and the insurer therefore protects participants' reasonable expectations.

\section{Which Rule of Employer Agency Should Courts Adopt?}

In developing a federal common law of agency, federal courts should take advantage of the experience gained while the law was in state hands. The options available to federal courts are the Boseman majority rule (employer as agent of the employee), the Elfstrom minority rule (employer as agent of the insurer), and the Paulson integrated rule (employer agency determined by nature of the tasks performed). ${ }^{1.38}$ Whichever state rule is adopted pursuant to ERISA must be specifically adapted to fulfill Congress's intent for the statute, which in this case is to protect plan beneficiaries. ${ }^{139}$

\section{The Boseman majority rule.}

The Boseman rule states that employers are generally the agents of the employees when negotiating or administering insurance plans. ${ }^{140}$ Boseman is now the majority state rule. ${ }^{141}$ When considering the Boseman rule as a candidate for adoption as the federal common law rule, four concerns stand out. First, a strict Boseman approach does not meet the requirements for adoption of state rules as federal common law interpreting ERISA because it does not create incentives or remedies that would reasonably protect plan beneficiaries as required by the statutory purpose of ERISA. ${ }^{142}$ Second, at its core, Boseman was concerned with conflict-of-laws problems, and the rule consequently does not give enough weight to protecting beneficiaries to pass muster as an ERISA rule. ${ }^{143}$ Third, Boseman itself, on which the majority rule is based, articulates a fact-sensitive standard that would provide a dif-

137 See Clements $v$ Continental Casualty Insurance Co, 730 F Supp 1120, 1124 (N D Ga 1989) (holding that "[b]ecause the employer is an agent of the insurer for purposes of premium collection," an insurer may not cancel an employee's policy when the employer negligently disobeys an employee's direction to remit payments to the insurer).

138 See Parts III.A-B.

139 Thomason $v$ Aetna Life Insurance Co, 9 F3d 645, 647 (7th Cir 1993) (holding that federal common law rules adopted pursuant to ERISA must comport with the purposes of that statute).

140 Boseman, 301 US at 204-05.

141 See Home Life Insurance Co v Chandler, 402 S2d 356, 359 (Miss 1981) (citing Boseman as the majority rule). See also note 90 (listing states that have adopted the majority rule).

142 See 29 USC $\S 1001 \mathrm{a}(\mathrm{c})(3)$ (1994) (setting forth protection of plan beneficiaries as a statutory purpose of ERISA).

143 Boseman, 301 US at 202 (stating that the issue is whether "the policy ... is governed by Pennsylvania law or Texas law"). 
ferent result in modern employer-administrator cases, given the divergence between the employer's interests and the employee's in those cases. ${ }^{144}$ Fourth, Boseman was an early decision; adopting it would bypass sixty-three years of the law's evolution in state courts.

As an initial matter, the majority rule does not fulfill the congressional intent for ERISA, and therefore should not be adopted. Whichever rule is adopted pursuant to the courts' authority to develop common law interpreting ERISA must be specifically adapted to serve the congressional purposes underlying that statute. ${ }^{145}$ One of the primary purposes of ERISA is the protection of plan beneficiaries. ${ }^{146}$ A strict adoption of the Boseman rule would allow insurers to escape payment of benefits based on employer misconduct or error when any other administrator chosen by the insurer would clearly have been considered the insurer's agent. ${ }^{1.77}$ The Boseman rule also suffers from the same incentive problems as preemption without replacement. If a strict Boseman approach is adopted, insurers will not have incentives to determine whether the employer-administrator is competent to administer the plan, or to monitor for misconduct in administration. ${ }^{14}$

Second, the Boseman court was more interested in the conflictof-laws ramifications of its agency determination than it was in the protection of plan beneficiaries. ${ }^{1.9}$ Boseman held that because the employer was the agent of the employee in negotiating the contract, the law of the state in which the contract was negotiated was to be applied. $^{150}$ Subsequent cases treated Boseman primarily as a conflict-oflaws decision. ${ }^{1.1}$ As the Court's discussion in Boseman demonstrates, an agency rule appropriate for solving a conflict-of-laws difficulty might have a very different focus from a rule regulating disputes arising from the employer's management of the plan. ${ }^{152}$ The unifying effect of ERISA preemption and development of a universally applied fed-

144 Id at 205 ("The undisputed circumstantial facts require the conclusion that the employer acted not as agent of the insurer but for and on behalf of petitioner and other insured employees and in its own interest.").

145 See note 139.

146 See 29 USC $\$ 1001 \mathrm{a}(\mathrm{c})(3)$. For more discussion of congressional intent and statutory purposes of ERISA, see Parts III.E.1-2.

147 See the discussion of Elfstrom, Part III.B.2.

148 For an excellent treatment of the difference between contract negotiation and employer administration settings, see Clements v Continental Casualty Insurance Co, $730 \mathrm{~F}$ Supp 1120,1124 (N D Ga 1989).

149301 US at 206 (explaining its holding as necessary to avoid the "confusion liable to result from applications of diverse state laws").

150 Id at 202-05.

151 See, for example, Ryder Truck Rental, Inc v UTF Carriers, Inc, 790 F Supp 637, 641-42 (W D Va 1992) (addressing Boseman in a section entitled "Choice of Law").

152301 US at 202-05 (focusing analysis on employer's relationships to insurer and employee with an emphasis on whether Texas or Pennsylvania law governs). 
eral common law would lessen the need for a strict Boseman approach, insofar as the Boseman Court was concerned that "inequalities and confusion liable to result from applications of diverse state laws shall be avoided." ${ }^{153}$

Third, Boseman itself actually articulates a fact-sensitive standard that is betrayed by subsequent courts' characterization of Boseman as an inflexible rule. Although the Boseman rule as cited by later cases is inflexible, the Boseman case itself actually relies on a fact-specific determination, not a hard and fast rule. ${ }^{1.4}$ This would seem directly to invite fact-specific adjudication of cases. The Boseman case, therefore, does not support what later courts refer to as the "Boseman rule." Under this view, the Boseman case has much more in common with the later Paulson fact-sensitive cases. ${ }^{156}$

Finally, Boseman, as a pre-Erie case, lacks the insight brought by the evolution of state law after federal courts were no longer able to determine federal common law. The Boseman rule was established in 1937 pursuant to the Court's authority to develop general federal common law under Swift v Tyson. ${ }^{157}$ The Court's subsequent decision in Erie reversed $S$ wift. ${ }^{158}$ As a result, the federal judiciary has not addressed the question of employer agency as a matter of federal common law for sixty-three years. In choosing whether to follow Boseman, courts have recognized that the case was, as Judge Friendly described it, "one of the last gasps of Swift $v$ Tyson.","

Boseman was not a poorly conceived rule based on its setting (negotiation of a contract). Boseman is one half of a good rule. In a contract negotiation setting the interests of the employer and employee are aligned. ${ }^{160}$ In these circumstances, a rule designating an em-

153 Id at 206.

154 See note 144.

155 See note 90 for cases following the non-fact-sensitive "Boseman rule."

156 See, for example, Paulson, 636 P2d at 942-43, 949; McCann v Washington Public Power Supply System, 803 P2d 334, 339 (Wash App 1991) (following Paulson and concluding that "a material question of fact exists whether the [employer] performed most of the administration of the ... life insurance policies, thus establishing an agency relationship").

15741 US 1,18 (1842).

158304 US at 79-80 (1938).

159 Nelson v Aetna Life Insurance Co, 359 F Supp 271, 294 (W D Mo 1973), quoting John Hancock Mutual Life Insurance Co v Schroder, 349 F2d 406, 407 (5th Cir 1965).

160 Boseman, 301 US at 204 ("Employers regard group insurance not only as [beneficial for] employees but also as advantageous to themselves."). As the law evolved after Boseman, courts noted that the presumption of agency delegation should vary according to whether the purpose of the delegation of agency was contract negotiation or plan administration. See, for example, Clements, 730 F Supp at 1124, citing Dawes Mining Co v Callahan, 246 Ga 531, 272 SE2d 267, 269 (1980). When an employer negotiates a health contract, his interests are aligned with his employees': he wants the best coverage for the least amount of money. Id. In a plan administration setting, however, the interests of the insurer and the employer are more closely aligned. For this reason, "issuance of the group insurance policy [is considered by some courts to be] the 'dividing 
ployer the agent of an employee makes sense. Since Boseman, however, the Paulson fact-sensitive approach has emerged, which distinguishes between Boseman negotiation settings and Elfstrom fullservice employer-administrator settings where the interests of the insurer and employer are aligned. ${ }^{161}$

\section{The Elfstrom minority rule.}

There are also serious problems with the adoption of a strict Elfstrom standard as the federal common law rule of employer agency. The first is a matter of practicality: the majority of states had adopted a Boseman-like rule before those laws were preempted. ${ }^{162}$ Federal adoption of a pure Elfstrom standard would disrupt the majority of agreements already in place. ${ }^{163}$ Second, the argument that the Elfstrom court found dispositive, namely that employees lack control over employers in their negotiations with insurers, assumes that employees would not choose to delegate to their employers authority to negotiate the terms of insurance policies in order to gain a better group health plan. ${ }^{164}$ This cannot always be the case. If the employee has an alternative to the group health program, such as the option to choose reimbursement for private insurance, then opting into a group health plan is significant; the employee joins the group insurance arrangement in the hopes of receiving superior coverage through group bargaining. ${ }^{165}$ To say that such a decision is not a delegation of authority to negotiate is logically suspect at best. The Elfstrom rule may therefore occasionally impede natural and desirable delegations of authority by employees to employers.

\section{E. The Integrated Paulson Rule}

1. The statutory purposes of ERISA support the adoption of the Paulson rule.

ERISA has a clear statutory purpose: to establish standards that protect "the interests of employees and their beneficiaries."

line' between situations where an employer is the agent of its employees and those where it is the agent of the insurer..." Clements, $730 \mathrm{~F}$ Supp at 1124.

161 Elfstrom, $432 \mathrm{P} 2 \mathrm{~d}$ at 737 (rejecting the argument that the interests of the employer and the employee coincide in employer-administration cases).

162 See note 90.

163 A similar argument could be raised against the Paulson rule; however, Paulson actually causes minimal conflict with existing regimes. See Part III.E.3.

164 See Matthew, 31 Wake Forest L Rev at 1043-44 (cited in note 130) (discussing benefits to employees of obtaining insurance through an employer).

165 Id.

166 See 29 USC $\$ 1001$ (a) (1994) (One of the major purposes of ERISA is to protect plan beneficiaries.). See also 120 Cong Rec at S 29933-35 (cited in note 7) (noting that the aim of the 
Paulson rule is the only approach that offers adequate remedies to employees while still allowing sufficient flexibility in the employeremployee relationship for situations in which an employee would wish to delegate authority to negotiate.

The Bosemian rule clearly fails to protect plan beneficiaries. ${ }^{167}$ ERISA's purpose is not served by a rule that unilaterally declares that the employer is always the employee's agent. ${ }^{168}$ Since Boseman is a market mimicking rule, ${ }^{169}$ and the market frequently fails to sufficiently protect beneficiaries, ${ }^{170}$ it follows that ERISA's beneficiary protection purpose will not be served by preemption without replacement, in which courts defer to the contract between the parties."

Although Boseman itself does not meet the requirements for adoption of a state rule pursuant to ERISA, it might present an obstacle to the adoption of the Paulson approach insofar as Boseman can be said to represent a reasoned judgment on the part of the majority of states that the lack of an agency remedy against insurers is acceptable. This argument is flawed, however, for several reasons. First, state employer-agency rules are now preempted by ERISA; any replacement rule must therefore be specifically adapted to serve the purposes of ERISA. ${ }^{172}$ While states adopting the Boseman rule were free to disregard protection of employee benefits as opposed to other considerations, ${ }^{173}$ courts considering a federal common law rule pursuant to ERISA do not have this luxury. Furthermore, state regimes had other safeguards for plan beneficiaries (such as punitive damages and causes of action for fraudulent denial of benefits) that ERISA does not pro-

pension reform that resulted in ERISA was to increase protection of plan beneficiaries).

167 See Zanglein, 72 Wash U L Q at 674-76 (cited at note 4).

168 See Part III.D.1, discussing how Boseman does not create incentives for employers to manage plans effectively.

169 See Cass R. Sunstein, Formalism and Statutory Interpretation: Must Formalism be Defended Empirically?, 66 U Chi L Rev 636, 645 (1999) (arguing that a market mimicking rule "replicate[s] what the parties would have done if they had made specific provision on the point"). In the insurance contract, there is no need to speculate what the parties (insurer and employer) would do on this point: they include no-agency clauses. See Torello v UNUM Life Insurance Co of America, 1999 US App LEXIS 32228, *13 (enforcing no-agency clause in insurance contract). The Boseman rule is market mimicking with respect to insurance contracts. The problem with this approach is that the employee has no say. Norby $v$ Bankers Life Co, 304 Minn 464, 231 NW2d 665, 669 (1975).

170 See Parts III.C.1-2 for a more complete discussion of the difficulties with allowing the market to govern employer-administrated insurance plans.

171 See Torello, 1999 US App LEXIS 32228 at *13 (relying on contract terms between employer and insurer in the absence of an agency relationship).

172 See note 139.

173 Consider the focus on conflict of laws in Boseman itself, which, since it was not adopted pursuant to ERISA, was free to concern itself more with avoiding varied state law than with ensuring employee protection. See Boseman, 301 US at 202 ("[T]he precise issue for decision is whether ... the policy provision requiring notice of claim is governed by Pennsylvania law or Texas law."). 
vide. ${ }^{174}$ Because ERISA lacks these other safeguards, even those state regimes which had adopted a Boseman rule were on balance far more protective of plan beneficiaries than an ERISA regime adopting the Boseman rule would be.

This makes a compelling argument for the Paulson standard. The Boseman rule cannot be adopted in its entirety because it fails to fulfill ERISA's statutory purposes, ${ }^{175}$ yet elements of the rule should be preserved. Boseman allows employee delegation of negotiation authority to employers when needed, and protects insurers from complaints that the employer-master policyholder did not speak for the employees when negotiating a contract or contract change with the insurer. The, Paulson rule integrates these valuable elements of the Boseman rule, yet still protects plan beneficiaries (when the insurer has delegated duties to the employer) in satisfaction of the statutory purposes of ERISA.

2. Only the Paulson rule fulfills congressional intent for ERISA as expressed in legislative history.

The Paulson integrated rule seems to be the type of rule envisioned by Congress. Legislative history contemporaneous with ERISA's passage indicates that Congress intended "to provide the full range of legal and equitable remedies available in both state and federal courts."

Subsequent legislative history also indicates that Congress intended federal courts to

shape legal and equitable remedies to fit the facts and circumstances of the cases before them, even though those remedies may not be specifically mentioned in ERISA itself. In cases in which, for instance, facts and circumstances show that the processing of legitimate benefit claims has been unreasonably delayed or totally disregarded by an insurer, an employer, a plan administrator, or a plan, the Committee intends the Federal Courts to develop a Federal common law of remedies. ${ }^{17}$

Therefore, where a fact-sensitive analysis indicates that legitimate claims are being disregarded by insurers, employers, or plan administrators (or any combination thereof), remedies are to be preserved by

174 See, for example, Dennis K. Schaeffer, Comment, Insuring the Protection of ERISA Plan Participants: ERISA Preemption and the Federal Government's Duty To Regulate Self-Insured Health Plans, 47 Buffalo L Rev 1085, 1086-89 (1999) (describing a gap created when Virginia law, which mandates coverage of injuries sustained in automobile accidents, is preempted).

175 See Part III.D.1.

176 HR Rep No 93-533, 93d Cong, 2d Sess 17 (1973), reprinted in 1974 USCCAN 4639, 4655.

177 Recommendation Report, HR Rep No 101-247 at 56 (cited in note 9) (emphasis added). 
the adoption of federal common law. Congress's goal closely matches the Paulson rule, which employs a fact-sensitive analysis to determine whether denial or delay of legitimate benefits by an employeradministrator should be remedied by the common law remedy of employer agency. ${ }^{178}$

Of the three approaches, the Paulson rule best fulfills the intent of Congress by preserving remedies for plan beneficiaries. Congress intended " $[\mathrm{t}]$ he enforcement provisions ... [of ERISA] to provide ... participants and beneficiaries with broad remedies for redressing or preventing violations of the Act." ${ }^{179}$ As previously discussed, Paulson provides employees with a remedy against an insurer when the employer-administrator makes an error or commits fraud. ${ }^{180}$ The Boseman rule (holding that the employer is almost always the agent of the employee with respect to an insurer) offers no remedy. ${ }^{181}$ Although the Elfstrom rule does offer beneficiaries protection against employer error or wrongdoing, a strict Elfstrom approach interferes with normal delegation to negotiate group insurance contracts and similar situations. $^{182}$ Again, the Paulson rule is more nuanced: it allows delegation of negotiation power in contract negotiation settings, but protects employees who have performed all of their obligations under the insurance contract from the employer-administrator's fraud or mistake. ${ }^{18}$ From the point of view of congressional intent, therefore, the integrated rule is the best approach.

3. Policy considerations support the adoption of the Paulson rule.

First, implementing the Paulson integrated and fact-sensitive rule will prevent a windfall to insurers in states that formerly adhered to the minority or integrated approach. ${ }^{184}$ Insurers are better able than employees to calculate the risk of loss due to employer-administrator error; in Elfstrom or Paulson states, where the insurer is liable for such

178 Paulson, 636 P2d at 939 (stating that even courts claiming to apply a minority or majority rule actually "base their decision upon the facts relating to the division of functions between the insurer and the employer-policyholder").

179 HR Rep No 93-533 at 17 (cited in note 176).

180 See Part III.B.3.

181 Boseman, 301 US at 204-05.

182 See, for example, Jones v Benefit Trust Life Insurance Co, 605 F Supp 179, 183 (S D Miss 1985) (rejecting claim that employee delegated negotiation power to employer in setting terms of group long term disability policy).

183 Paulson, $636 \mathrm{P} 2 \mathrm{~d}$ at $941-42$ (finding the employer the insurer's agent when performing delegated responsibilities); Clements v Continental Casualty Insurance Co, $730 \mathrm{~F}$ Supp 1120, 1124-25 (N D Ga 1989) (holding that employer is the agent of the employee in contract negotiation settings and that employer is the agent of the insurer in plan administration settings).

184 See Home Life Insurance Co v Chandler, 402 S2d 356, 359 (Miss 1981) (listing minority rule states that follow Elfstrom). See also note 93. 
losses, insurers will have passed these costs on to their customers. Preemption of state laws by ERISA without replacement, or adoption of the Boseman rule, will result in an unbargained-for windfall to insurers in Elfstrom or Paulson states because insurers will have collected higher premiums to cover a risk of loss they no longer bear.

Insurance companies, however, will certainly pass on increased costs of providing insurance (created by Paulson or Elfstrom rules) to customers. Insurers are, after all, in the business of spreading risks.

The opposite is not true: employees are unlikely to bargain effectively for lower premiums compensating for the increased risk of loss because of employer fraud or error, due to lack of good information about the risks. ${ }^{185}$ Even if employees and employers were aware of changes in insurance law (an implausible assumption), they would not be able to share the burden with employers and the insurance industry as easily. Further, there is a risk that employers will hold back the savings created by the law. As the above indicates, insurers are the party best able to sustain a change in the law.

An objection to the Elfstrom rule is that a sudden shift to it would disrupt existing contracts; ${ }^{185}$ it is worth considering whether the Paulson rule creates the same problem. The Paulson rule in fact will cause the least conflict with existing contracts because it integrates the two existing strands of state law. Paulson preserves the ability of parties to make sensible delegations to negotiate, and it establishes incentives for insurers (as under Elfstrom) to provide for competent administration. ${ }^{187}$ The fact that Paulson will block the ability of insurers and employers to contract out of agency should not matter, since agency is not determinable by stipulations of the parties. ${ }^{188}$ Insurers and employers are (as repeat players) necessarily aware of the fact that agency obligations arise out of their actions, and thus they will not be taken by surprise if a court finds that the employer and insurer are in an agency relationship. ${ }^{189}$ An integrated approach will be more true

185 The prime difficulty is that employees do not have the same information as employers, and for this reason, cannot bargain effectively. Norby $v$ Bankers Life Co, 304 Minn 464, 231 NW2d 665, 669 (1975).

186 See Part III.D.2 (analyzing the Elfstrom rule as a possible model for federal common law).

187 Paulson, 636 P2d at 948 (referring to group insurance as a "functionally distinct and efficient system of distribution").

188 See note 125.

189 It is important to note that clear rules may still be promulgated under the integrated approach, so that employers and insurance agencies are not left guessing as to how their relationship will be characterized. See, for example, Clements $v$ Continental Casualty Insurance Co, $730 \mathrm{~F}$ Supp 1120, 1124 (N D Ga 1989) ("[I]ssuance of the group insurance policy is the 'dividing line' between situations where an employer is the agent of its employees and those where it is the agent of the insurer.") (citation omitted). 
to the expectations of parties than would either the Elfstrom or Boseman rule alone.

Another concern about the Paulson standard is that it will be too time consuming for courts to engage in case-by-case fact-specific adjudication. ${ }^{190}$ A similar concern is that, for the same reason, Paulson will provide insufficient advance notice to employers and insurers that their administration arrangements will be deemed an agency relationship.

Paulson, however, sets forth a bright line rule of its own: "In the performance of a function delegated by the insurer to the employer, the employer is deemed to be the agent of the insurer." dard should provide adequate guidance to parties, while still allowing the courts the critical flexibility to recognize when employers and insurers are engaging in evasive conduct (for example, structuring the relationship to avoid the imputation of agency).

\section{CONCLUSION}

Congress has instructed the federal judiciary to construct federal common law remedies needed to replace state laws preempted by ERISA where a fact-sensitive analysis shows that plan benefits are being unreasonably delayed or disregarded by insurers, employers, and plan administrators. ${ }^{12}$ Federal courts had already begun to develop a federal common law of employer agency prior to Erie, and now have renewed authority to continue development of that common law under ERISA. The statutory purposes of ERISA support the adoption of a fact-sensitive rule similar to the approach in Paulson. Congressional intent, as expressed in legislative history, also supports the adoption of this integrated approach. ${ }^{193}$ Common sense principles of equity and fairness require a rule that allows beneficiaries, who have fulfilled their obligations under their insurance contracts, a remedy to recover the benefits of their bargain. Federal courts should adopt the fact-sensitive Paulson rule for the determination of employer agency as a matter of federal common law pursuant to ERISA.

190 Some areas of law are not amenable to case-by-case analysis. See, for example, Wilson $v$ Garcia, 471 US 261, 272 (1985) (holding that in the statute of limitations context, analysis of the particular facts of each claim "inevitably breeds uncertainty and time-consuming litigation"). A substantial majority of courts recently examining employer agency questions have chosen factspecific analyses. See Golt v Aetna Life Insurance Co, 2000 Mont 155, 2 P3d 841, 848-49.

191 Paulson, 636 P2d at 941.

192 HR Rep No 93-533 at 17 (cited in note 176).

193 See Part III.E.1-2. 